\title{
Дослідження вирорбництва та роботи торгового холодильного обладнання
}

\section{І. О. Константинов ${ }^{凶}$, М. Г. Хмельнюк, О. Г. Федоров}

Одеська національна академія харчових технологій, вул. Канатна 112, Одеса, 65039

$\triangle$ e mail: ikonstantinov9@gmail.com

\begin{abstract}
Проведено аналіз виробництва і роботи морозильного ларя з моніторингом температур та енергозатратами системи при отримання штучного холоду. Описані технічні характеристики торгівельного холодильника моделі M400S+. Показана доцільність створення комплексної моделі розрахунку торгового холодильного обладнання, для підвищення його ефективності та скорочення часу на проектування.
\end{abstract}

Ключові слова: Холодильне обладнання; Температура; Енергоспоживання.

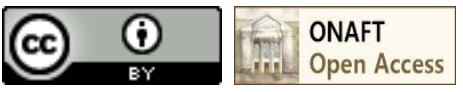

\section{1. Вступ}

Аналіз інвестицій в холодильну галузі мають високі темпи розвитку. Найбільш поширене застосування мають холодильні технології в сфері збереження і торгівлі продуктами харчування, адже всі продукти, для збільшення терміну їх придатності, потребують певних умов зберігання [1].

Асортимент продукції торгівельного холодильного обладнання різноманітний i включають як автономні так і вбудовані холодильні системи: охолоджувачі, морозильні апарати, охолоджувачі напоїв, обладнання для охолодження харчових продуктів, торгові автомати для виробництва льоду i охолоджувачі води, вертикальні холодильні вітрини, холодильні шафи, камери, агрегати та ін. Обладнання, яке використовується в цих додатках, має типовий термін придатності від 10 до 20 років і відносяться до комерційного холоду 3 малим розміром заряду холодоагенту (як правило $0,1-6,5 \kappa г)$.

Аналіз показує що споживання енергії в роздрібних супермаркетах холодильним обладнанням часто $\epsilon$ найбільшим енергонавантаженням.

Енергоспоживання супермаркетів залежить від бізнесу, послуг, формату магазину, товарного набору, торгової активності та обладнання, яке використовується для приготування їжі в магазині та зберігання. Річне споживання електроенергії може сильно відрізнятися від приблизно 700 кВт / год., в зручних магазинах, до більш ніж 2000 КВт-год в гипермаркетах [2]. Холодильні системи використовувають від 30\% до 60\% електроенергії, тоді як освітлення та інші комунальні послуги становить від $15 \%$ i $25 \%$.

У даній роботі розглянуто розвиток торговельної техніки на Україні на прикладі виготовлення морозильних ларів компанії ТОВ «ЮКА-Інвест» $[3,4]$.

\section{2. Основна частина}

Холодильні системи що використовуються в продукції ТОВ «ЮКА-Інвест» $\epsilon$ класичною. Схожі системи використовуються у багатьох промислових холодильниках, та торговому холодильному обладнанні. Дана схема (рисунок 1) включає в себе типові, основні чотири елементи (компресор, конденсатор, дросельний пристрій та випарник) та два додаткових теплообмінники (теплообмінник для зняття перегріву та РТО типу труба в трубі). На діаграмі (рисунок 2) показані принципові процеси в одноступеневі холодильні системі відповідно схеми. Схема та цикл роботи холодильних систем можуть відрізнятися відповідно моделям, холодильним агентам, комплектації обладнання та іншим факторам.

\section{Виробництво торгового холодильного обладнання}

Існує безліч варіацій виробництва торгового холодильного обладнання.

Принцип виробництва холодильного торговельного обладнання розглянемо на прикладі морозильного ларя, моделі M400S+ (рисунок 3), який розроблений відповідно до системи стандартів ISO 23953-2: 2005 (Е).

Морозильний ларь має відносно нескладне виробництво. Він складається 3 двох основних елементів (внутрішнього, та зовнішнього корпусу що з'єднуються за рахунок пінополіуретану. Верхня частина скрині, окрім декоративної функції, являється також елементом з'єднання двох корпусів, несучою частиною тари, та місцем розташування доступу до внутрішнього об'єму. 3 боку ларя, або під ним знаходиться компресорний відсік, доступ в корпус, в залежності від моделі, розсувні дверцята, або кришка. В залежності від комплектації моделі, ларі встановлені на коліса, або ніжки, а в залежності від продукту зберігання 


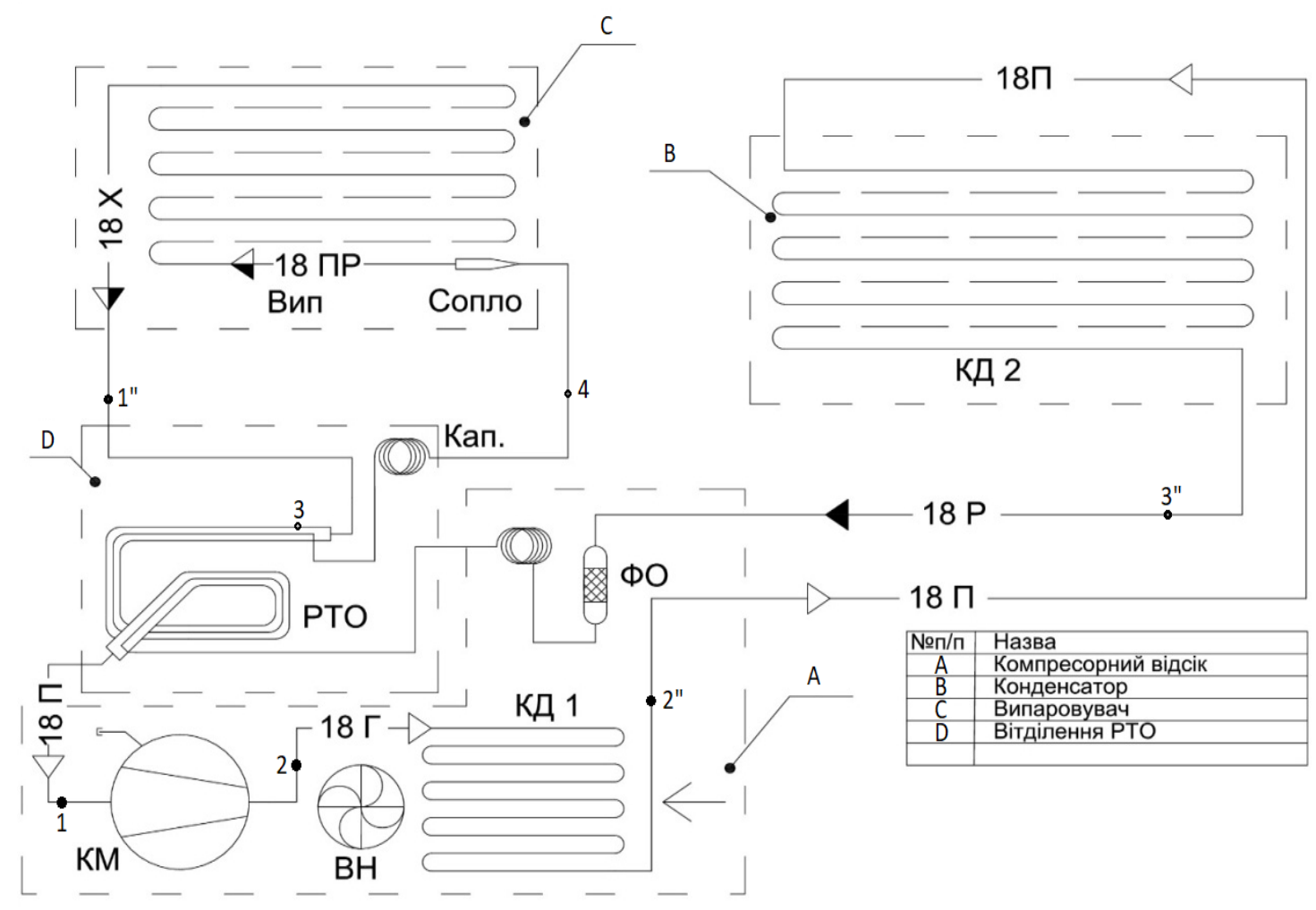

КМ - компресор; КД1 - теплообмінник для зняття перегріву; КД2 - конденсатор; ФО - фільтр; PТО - рекуперативний теплообмінник; Кап. - капілярна трубка. Сопло - редукційна трубка;

Вип - випарник; ВН - електродвигун з крильчаткою.

Агрегатний стан холодильного агенту:

$18 \Gamma$ - арячі пари холодильного агенту; 18П - ари холодильного агенту; 18Р - рідкий холодильний агент; 18ПР - аро-рідинна суміш; 18Х - переохолоджений холодильний агент.

Рисунок 1 - Принципова схема холодильної системи

тарою можуть виступати корзини або гастрономічні ємності.

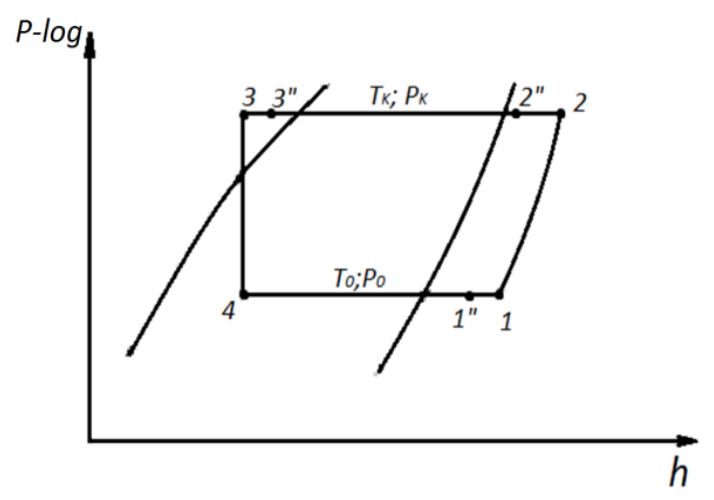

Процеси на діаграмі: 1-2 - Стиснення парів холодильного агенту в компресорі; 2-2" - зняття перегріву в теплообміннику КД1; 2"-3" - конденсація в теплообміннику КД2; 3"-3 - переохолодження рідини в РТО; 3-4 дроселювання холодильного агенту в дросельному пристрої Кап.; 4-1” - кипіння холодильного агенту в теплообміннику Вип.; 1"-1 - перегрів пари в теплообміннику типу РТО.

Рисунок 2 - Індикаторна діаграма P-log h
На рисунку 3 представлено ларь 3 місцем розташування комплектуючих елементів.

Модель повністю відповідає продукції що на сьогоднішній день випускається в серійному виробництві.

Дана комплектація моделі передбачає чотири теплообмінники, в ролі яких виступають:

-листотрубний випарник 3 витків деформованої, алюмінієвої трубки 3 зовнішнім діаметром 8 мм. та товщиною стінок 1.5 мм. спірально намотаної по контуру зовнішньої частини внутрішнього корпусу. Трубка проклеєна алюмінієвою клейкою стрічкою по всій довжині та знаходиться в ізоляції корпус;

-листотрубний конденсатор що являє собою стальну трубку спірально проклеєну алюмінієвою клейкою стрічкою по внутрішні частині зовнішнього корпусу;

- теплообмінник для зняття перегріву розташований в компресорному відсіку має вигляд спіральної трубки встановленої на спеціально вифрезеруваних стійках. Тепловідвід в даному теплообміннику відбувається за рахунок примусового руху повітря що створює крильчатка електродвигуна. Розміщення даного теплообмінника електродвигуна та компресора послідовні, за для одночасного відведення тепла від теплообмінника, та охолодження компресора. 

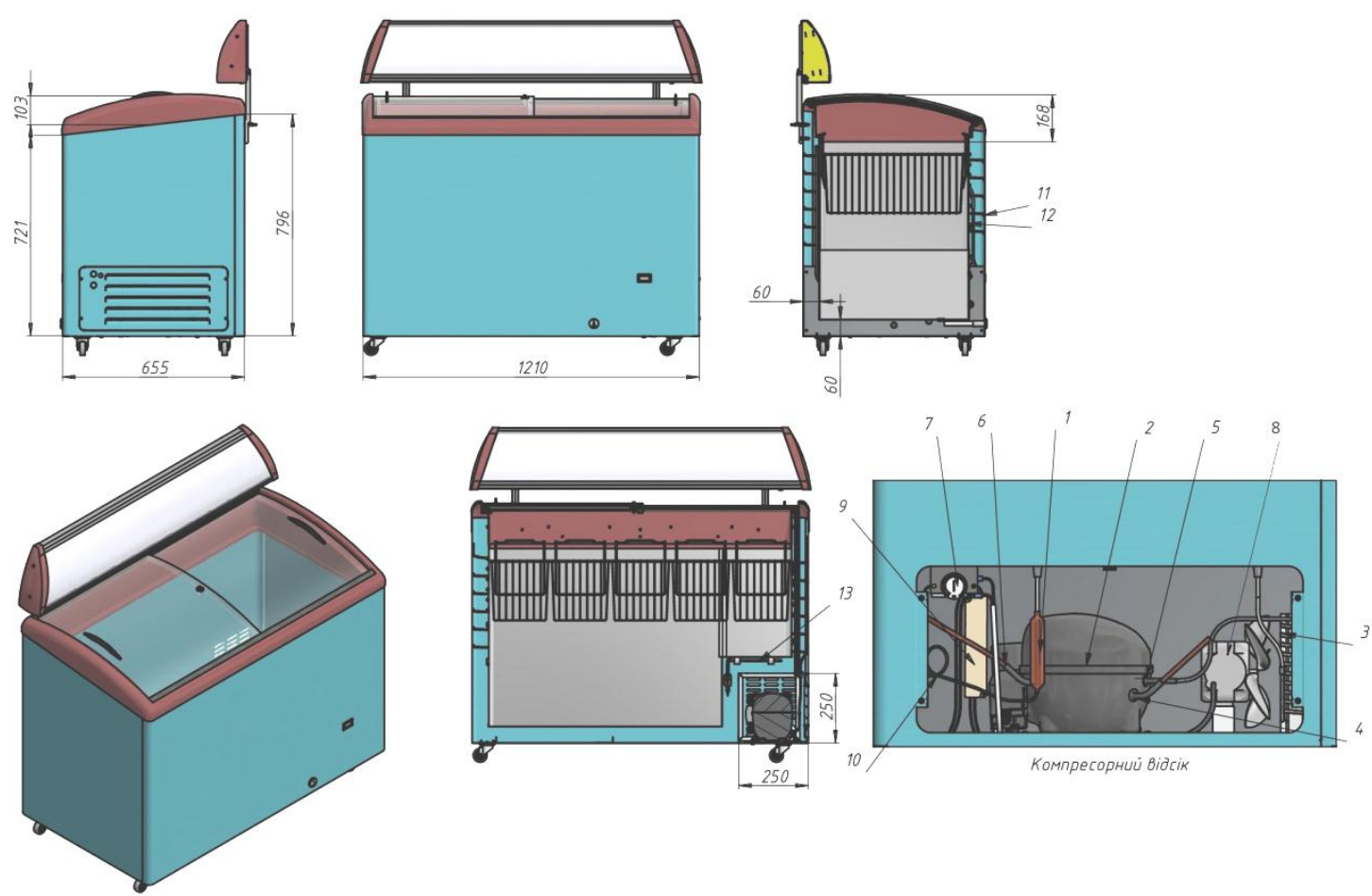

1 - фільтр; 2 - компресор; 3 - теплообмінник для зняття перегріву; 4 - заправний патрубок;

5 - трубопровід високого тиску; 6 - трубопровід низького тиску; 7 - терморегулятор (термостат); 8 - електродвигун; 9 - блок живлення 12V LED освітлення; 10 - капілярна трубка (дросельний пристрій); 11 - зовнішній корпус; 12 - внутрішній корпус; 13 - рекуперативний теплообмінник.

Рисунок 3 - Холодильний ларь моделі M400S+.

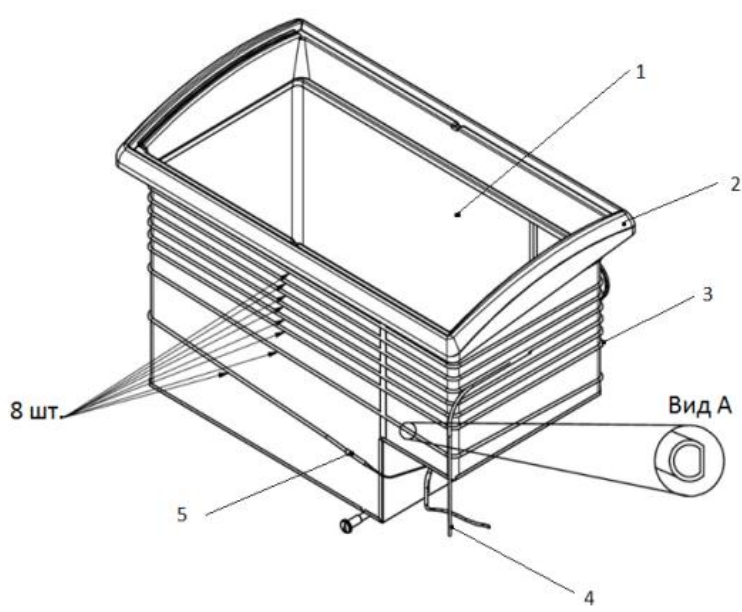

1 - корпус випарника; 2 - корона; 3 - змієвик випарника; 4 - кріплення чутливого елементу терморегулятора; 5 - кісце під'єднання капілярної трубки. Вид А - вигляд трубки випарника в розрізі.

Рисунок 4 - Випарник

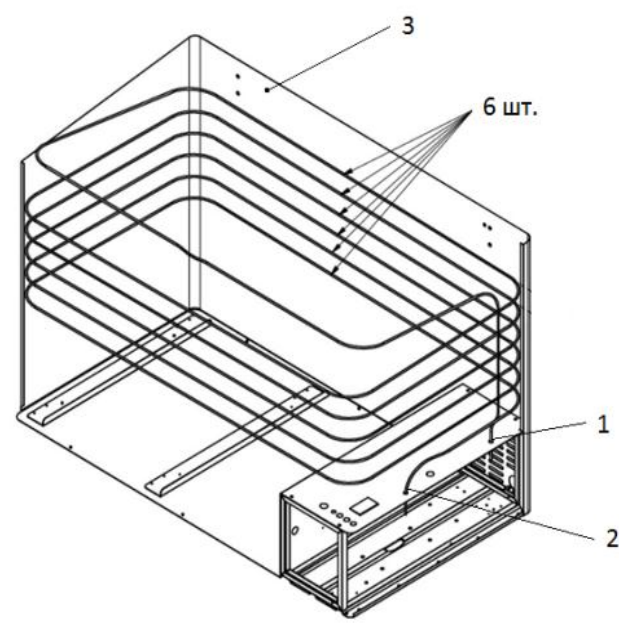

1 - трубка підведення холодильного агенту до випарника; 2 - трубка відведення холодильного агенту від конденсатора. 3 - зовнішній корпус.

Рисунок 5 - Конденсатор 


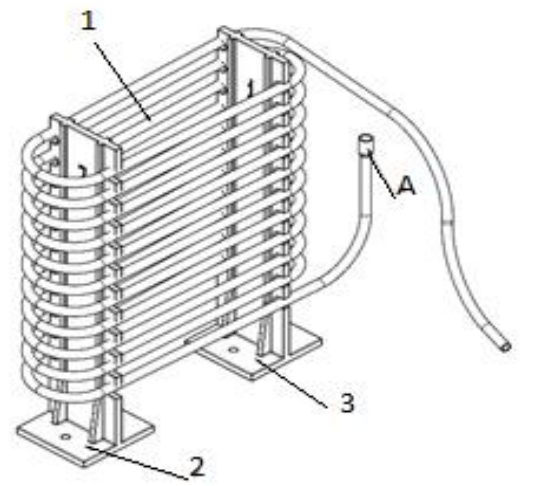

1 - намотка трубки теплообмінника у вигляді спірального змієвика; 2 - стійка теплообмінника №1; 3 - стійка теплообмінника №2. А - розширення трубки теплообмінника заради з'єднання пайкою з трубкою входу до конденсатора.

\section{Рисунок 6 - Теплообмінник для зняття перегріву}

- РТО представлене у вигляді теплообмінника труба в трубі. Його головною функцією являється перегрів парів на вході в компресор (запобіганню вологому ходу) та переохолодження холодильного агенту в капілярні трубці, заради збільшення холодопродуктивності.

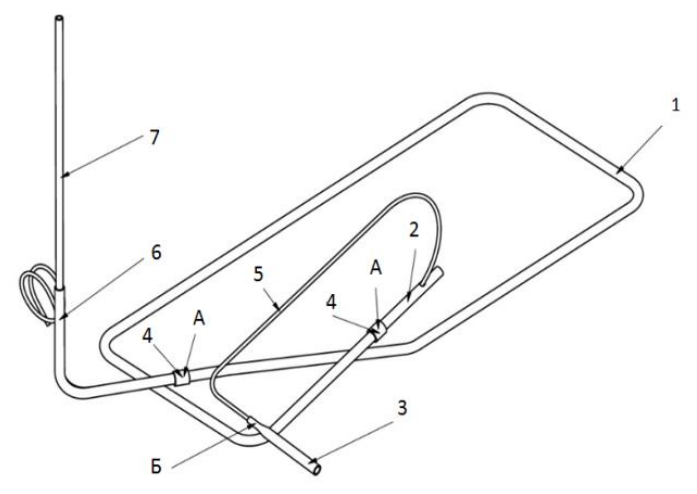

1 - зовнішня (алюмінієва) трубка РТО; 2 - мідна трубка (місце виведення внутрішньої трубки теплообмінника); 3 - сопло (редукційна трубка) місце з'єднання з випарником; 4 - Lokring (3'єднувальна одиниця); 5 - капілярна трубка; 6 - мідна трубка (місце підведення внутрішньої трубки теплообмінника); 7 - мідна трубка (магістраль під'єднання до лінії низького тиску в компресорі). А - місце розвальцювання алюмінієвої трубки РТО, за для з'єднання іiі через Lokring з мідною трубкою; Б - місце зменшення діаметру редукційної трубки, заради з’єднання пайкою 3 дроселюючим пристроєм.

\section{Рисунок 7 - Рекуперативний теплообмінник}

В цілому асортимент продукції складається 3 морозильних шаф з прямим склом, 3 гнутим склом, 3 глухою кришкою для зберігання та експозиції всіляких продуктів при низьких температурах; стелажі, кондитерські вітрини, вітрини для овочів і фруктів, гастрономічні вітрини, вітрини для торгівлі через прилавок, холодильні та морозильні шафи, вітрини під м'яке морозиво, і маса додаткових опцій. Морозильні скрині об'ємом від 100 до 1000 літрів. і морозильні бонети. Різноманітність продукції включає в себе понад 25 моделей 3 різноманітними об'ємами та температурними режимами.

Холодильні шафи працюють в діапазоні $+1 \ldots+12{ }^{\circ} \mathrm{C}$. Морозильні шафи працюють в діапазоні $-12 \ldots-22{ }^{\circ} \mathrm{C} ., 3$ глухою та прозорою дверцятами призначені для охолодження та зберігання продукції при застосуванні примусової конвекції повітря, що сприяє рівномірному розповсюдженню температури в об'ємі.

Пропонується додаткові опції такі як: розморожування гарячими парами, розморожування електричними тенами, електронні замки, рекламний лайтбокс, LED освітлення, цифровий термометр то що.

Маючи великий асортимент продукції, та включаючи потреби споживача, виникає безліч проблем, що потребують технологічних рішень та вдосконалення. Проаналізувавши продукцію ТОВ «ЮКА-Інвест» за певний період часу, було виявлено наступні недоліки:

- оскільки скрині та бонети не являються герметичними, а обладнані розсувними скляними дверцятами чи кришками, вологе повітря частково потрапляє в охолоджуваний об'єм, що сприяє утворенню снігової шуби на стінках випарника. Данна проблема передбачає збільшенню теплових навантажень в камеру, підвищенню енергетичних затрат на виробництво холоду, підвищенню температури в охолоджуваному об'ємі та навіть вологому ходу компресору. Відповідно данні проблеми тягнуть за собою низку інших проблем що призводять до аномальної роботи агрегатів та поломок;

- вся продукція проходять тестування в певних кліматичних класах, в яких передбачено сталі тепловологісні умови. В наслідок при визначених умовах навколишнього середовища, в деяких моделях на склі досягається точка роси. Як наслідок на склі утворюється конденсат що зменшує ергономічні властивості та створює дискомфорт споживачам;

- використання додаткових опцій, встановлення електронного термометра, чи контролера передбачають визначення місця розташування чутливих елементів додаткового обладнання. зважаючи на великий асортимент, місця розташування датчиків відрізняються, тому для винесенням остаточного рішення проводиться безліч лабораторних тестів та створення нових прототипів;

- підприємство виготовляє за одну зміну приблизно 200-250 одиниць продукції. Так як виробництво конвеєрне, продукція потребує постійного контролю, вдосконалення універсалізації та уніфікації продукції. Від цього залежить якість продукції, та її кількість. Але після нанесення будь яких змін, потрібно враховувати не тільки результат на виробництві, а і вплив даної зміни на роботу агрегатів. Це знову спонукає на створення прототипів, та проходження ними ряду тестів в дослідницькі дільниці; 
- на виробництві постійно ведеться робота над здешевленням конструкції, та максимальну незалежність від по сторонніх поставників. Це передбачає зменшення собівартості продукції та підвищенню незалежності фірми. Однак всі нововведення не повинні нести негативний вплив на роботу систем, та повинні бути обгрунтовані;

- нормативна та технологічна документація, виготовлена технологічним відділом знаходиться на всіх дільницях виробництва за для підвищення ефективності та якості виконання робіт. Та оскільки ведеться постійне удосконалення та розробки, після їх затвердження, вона потребує безперервного оновлення. Затримка в оновленні даних паперів передбачає порушення в процесі виготовлення продукції, і як наслідок зменшення продуктивності підприємства в цілому.

При виготовленні холодильних агрегатів 3 капілярною трубкою, необхідні теплові розрахунки обладнання. Здебільшого підбір обладнання, на нові, або прототипні моделі, проводиться експериментальним шляхом, численними лабораторними дослідами та тестами. При розробці морозильного ларя, моделі M400S+ були використані експериментальні дослідження 3 розробкою математичної моделі і методики розрахунку даного обладнання. Така методика значно зменшує час підбору і комплектації обладнання.

Однак наведені вище приклади $є$ лише частиною запитань що потребують вирішення, оскільки розробка та вдосконалення проводиться безперервно.

\section{3. Результати досліджень}

Найважливішим показником роботи холодильної системи є задана температура охолодження.

Температура в обладнані визначається правилами безпеки продуктів харчування, стандартів та власних специфікацій супермаркетів. Однак між рекомендованою температурою та реальною іноді можуть спостерігатися відмінності. Це може бути обумовлено до змін у положенні контрольної температури зонда, налаштування або варіанти використання приладу.

В лабораторних умовах проведений температурний тест моделі M400S+. По холодильні системі було розміщено п'ять датчиків температури в наступних місцях: На лінії нагнітання а відстані 100мм. від компресора, на виході 3 теплообмінника для зняття перегріву; На фільтрі (кінець конденсації); На лінії всмоктування на відстані 100 мм. від компресора; На лінії завантаження продукції.

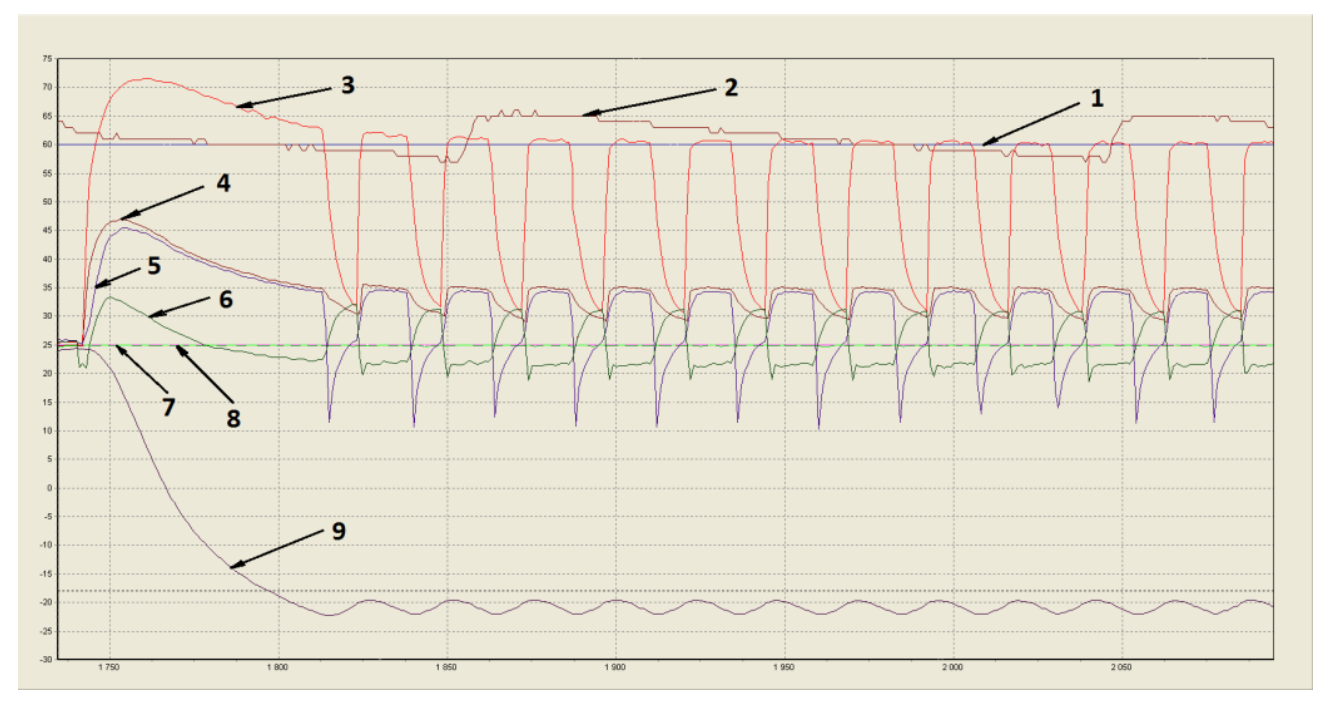

Рисунок 8 - Залежність температури від часу

На рисунку 8 показана залежність температури в різних точках ларя від часу.

Також на графіку присутні показання навколишнього середовища в момент проведення досліду. Задане значення вологості (графік №1) $h p$ дорівнює 60\% та коливається в діапазоні 8\% (графік №2.). Задана температура навколишнього середовища (графік №7) $t_{\mathrm{oc}}$ дорівнює $25^{\circ} \mathrm{C}$ та коливається в межах $0.2^{\circ} \mathrm{C}$ (графік №8), ці показники відповідають третьому кліматичному класу.

На представленому на рисунку 3 графіку лінія №3 відповідає температурі холодильного агенту при виході 3 компресора. Пік цієї температури відповідає $72-73^{\circ} \mathrm{C}$, та припадає на початок роботи агрегату. Саме в цей час в охолоджуваному об'ємі температура найвища, i відведення тепла є найбільш інтенсивним.
Таблиця 1 - Кліматичні класи

\begin{tabular}{|c|c|c|c|c|}
\hline $\begin{array}{c}\text { Кліматич- } \\
\text { ний клас } \\
\text { випробуваль } \\
\text { ної ділянки }\end{array}$ & $\begin{array}{c}\text { Темпера- } \\
\text { тура су- } \\
\text { хого тер- } \\
\text { мометра }\end{array}$ & $\begin{array}{c}\text { Віднос } \\
\text { на } \\
\text { воло- } \\
\text { гість }\end{array}$ & $\begin{array}{c}\text { Точка } \\
\text { роси }\end{array}$ & $\begin{array}{c}\text { Маса водя- } \\
\text { ної пари в } \\
\text { сухому } \\
\text { повітрі }\end{array}$ \\
\hline № п/п & $\mathbf{0}^{\mathbf{C}}$ & $\mathbf{\%}$ & $\mathbf{0}$ & г/кг \\
\hline 0 & 20 & 50 & 9,3 & 3 \\
\hline 1 & 16 & 80 & 12,6 & 9,1 \\
\hline 2 & 22 & 65 & 15,2 & 10,8 \\
\hline 3 & 25 & 60 & 16,7 & 12 \\
\hline 4 & 30 & 55 & 20 & 14,8 \\
\hline 6 & 27 & 70 & 21,1 & 15,8 \\
\hline 5 & 40 & 40 & 23,9 & 18,8 \\
\hline 7 & 35 & 75 & 30 & 27,3 \\
\hline 8 & 23,9 & 55 & 14,3 & 10,2 \\
\hline
\end{tabular}


При досягненні заданої температури в камері, температура на нагнітанні опускається до $31-32^{0} \mathrm{C}$. Це характерно для капілярних холодильних систем, оскільки під час «сплячої» фази агрегату в системі вирівнюються тиски, а, відповідно, і температури змінюються інтенсивніше. При нормальній роботі агрегату в системі на нагнітання становить $62-63^{\circ} \mathrm{C}$.

Температура на виході з теплообмінника КД1 (лінія графіку №5.) має схожі параметри 3 графіком температури на нагнітанні, але в значно меншому діапазоні. Цей перепад, і є наслідком зняття перегріву. Пік температури на виході з КД1 складає $46-47^{0} \mathrm{C}$. Під час «сну» системи опускається до $30-28^{0} \mathrm{C}$ а при нормальному режимі роботи рівна $35^{\circ} \mathrm{C}$. Перепад температур між нагнітанням, та кінцем роботи теплообмінника для зняття перегріву складає $27-28^{0} \mathrm{C}$.

Температура кінця конденсації (лінія графіку №4.), при виході на режим, де що нижча від температури при виході 3 КД1 i при максимальному навантаженні становить $45-46^{0} \mathrm{C}$. Це свідчить що КД1 повністю знімає перегрів, i процес конденсації походить в ізотермічно, ап. Пониження температур на $1-2^{0} \mathrm{C}$ свідчить про переохолодження холодоагенту в КД2. У момент переходу системи у «сплячий режим» температура на фільтрі різко опускається, це зумовлене інтенсивним скіпанням холодильного агенту в фільтрі та капілярні трубці. При цьому температури досягають $9-10^{\circ} \mathrm{C}$. Після чого температура знову починає підійматися, оскільки в системі відбувається вирівнювання тисків і рідкий холодильний агент по волі перетікає в випарник. В момент пуску компресора, температура швидко підіймається до робочої, і становить $34^{0} \mathrm{C}$.

На початку виходу на режим, температура на лінії всмоктування (лінія рафіку №7) опускається на $4-5^{\circ} \mathrm{C}$ в низ, що пояснюється інтенсивним википанням холодильного агенту 3 випарника, який там зібрався після повного вирівнювання тисків у системі. Потім температура підіймається до критичної температури в $34-33^{\circ} \mathrm{C}$ і по волі заповнення випарника рідким холодильним агентом, та відведенням тепла 3 охолоджуваного об'єму опускається до нормальної, робочої температури в $22-23^{\circ} \mathrm{C}$. Ця температура включає в себе роботу РТО. Після досягнення заданої температури система переходить в «сплячий» режим, температура на трубопроводі всмоктування росте. Цей процес зумовлений вирівнюванням тисків, заповненням випарника рідким холодильним агентом, та тепловим навантаженням на трубопровід від компресора. В момент увімкнення температура різко опускається до $18-19^{\circ} \mathrm{C}$, інтенсивним википанням рідкого холодильного агенту що зібрався в випарнику, та підвищенням її до нормальної, робочої температури.

3 моменту увімкнення температура на лінії завантаження (лінія графіку №9), при цьому вихід на режим складає приблизно 60-70 хв. Досягнувши заданої температури, теплове реле розмикає електричний контур, і по волі тепло надходження, температура знову підіймається. Нижня температура діапазону роботи складає $-23^{0} \mathrm{C}$; верхня температура діапазону роботи складає $-19^{\circ} \mathrm{C}$.

Оскільки відповідно характеристикам термостату його температура спрацювання дорівнює $36^{\circ} \mathrm{C} \pm 1^{0}$ та розташуванню чутливого елемента на 5-й трубці випарника, справедливим буде висновок, що температура кипіння дорівнює $35-37^{0} \mathrm{C}$.

Таблица 2 - Температури роботи холодильної системи морозильного ларя

\begin{tabular}{|l|c|c|c|c|}
\hline \multicolumn{1}{|c|}{ Назва } & $\begin{array}{c}\text { Пікова } \\
\text { темпе- } \\
\text { ратура, } \\
\text { 0С }\end{array}$ & $\begin{array}{c}\text { Робоча } \\
\text { темпе- } \\
\text { ратура, } \\
\text { 0C }\end{array}$ & $\begin{array}{c}\text { Темпе- } \\
\text { ратура в } \\
\text { момент } \\
\text { старту, } \\
\mathbf{0} \mathbf{C}\end{array}$ & $\begin{array}{c}\text { Темпе- } \\
\text { ратура в } \\
\text { момент } \\
\text { вимкне- } \\
\text { ння, } \mathbf{0}\end{array}$ \\
\hline Нагнітання & $72-73$ & $62-63$ & $32-31$ & $61-62$ \\
\hline $\begin{array}{l}\text { Зняття } \\
\text { перегріву }\end{array}$ & $46-47$ & $35-34$ & $30-28$ & 34 \\
\hline $\begin{array}{l}\text { Кінець } \\
\text { конденсації }\end{array}$ & $45-46$ & 34 & $30-31$ & $9-10$ \\
\hline Всмоктування & $34-33$ & $22-23$ & $18-19$ & 22 \\
\hline $\begin{array}{l}\text { Лінія } \\
\text { завантаження }\end{array}$ & $24-25$ & -22 & -19 & $-23-(-24)$ \\
\hline
\end{tabular}

Результати отримані за допомогою польської системи контролю та моніторингу тепловологісного режиму «GECO». Дослідницька дільниця має чотири основних джерела живлення, в електричний ланцюг яких увімкнені мультиметри моделі SAIA PCD ALD1D5F. Зняття показань 3 даної моделі дають змогу отримати фактичні та номінальні показники потужності, силу струму та напругу в системі.

Замір проводився в третьому кліматичному класі, який відповідає умовам роботи торгового холодильного обладнання в закритому приміщенні 3 системою вентиляції (магазин, супермаркет універсам).

Отримані значення заміру електроенергії, проведеного на протязі 28 годин, приведено в таблиці 3.

Таблиця 3 - Показники споживання електроенергії

\begin{tabular}{|l|c|}
\hline \multicolumn{1}{|c|}{ Назва заміру } & Одиниці \\
\hline $\begin{array}{l}\text { Фактична потужність за 28 годин, } \\
P_{\text {раrt }}(\text { кВт/28 год). }\end{array}$ & 3.6 \\
\hline $\begin{array}{l}\text { Споживана потужність на годину, } \\
P \text { (кВт/год). }\end{array}$ & 0.14 \\
\hline $\begin{array}{l}\text { Розрахункова потужність за добу, } \\
P_{\mathrm{P}} \text { (кВт/добу) }\end{array}$ & 3.1 \\
\hline $\begin{array}{l}\text { Сила електричного струму, } \\
I \text { (А). }\end{array}$ & 1.6 \\
\hline $\begin{array}{l}\text { Напруга в системі, } \\
U \text { (В). }\end{array}$ & 226 \\
\hline
\end{tabular}

\section{Висновок}

Проведений аналіз обгрунтував необхідність створення єдиної комплексної системи розрахунку торгового холодильного обладнання для підвищення енергоефективності та зменшенні часу на проектування.

Лабораторно-аналітичного дослідження показало необхідність розрахунку і підбора обладнання за умов збереження чи зменшення собівартості продукції, та дали можливість створити умови для внесення змін і корективів в холодильну систему для переходу на нові холодильні агенти. 


\section{Література}

1. Evans, J.A., and Swain, M.V.L., 2010. Performance of retail and commercial refrigeration

systems. IIR ICCC2010, Cambridge, UK.

2. Tassou, S.A., Ge, Y., Hadawey, A. and Marriott, D.,

2011. Energy consumption and conservation in food retailing, Applied Thermal Engineering, Volume 31, Issue 2, 2011, Pages 147-156.

3. Juka: сайт підприємства. [Електроний ресурс] Режим доступу: https://juka.ua/

4. Juka: сайт партнерів. [Електроний ресурс] Режим доступу: http://juka.com.pl/

Отримана в редакції 04.07.2018, прийнята до друку 04.09.2018

\title{
Research Production and Work of Trade Refrigerating Equipment
}

\author{
I. A. Konstantinov, M. G. Khmelniuk, O. G. Fedorov \\ Odessa National Academy of Food Technologies, st. Kanatna 112, Odessa, 65039, Ukraine
}

\begin{abstract}
The analysis of the production and operation of the freezer lava with the monitoring of temperature of the system and energy consumption of the system in the case of artificial cold. Based on investigations performed, the article describes the processes of selection of components for the refrigeration system and describes the methods for researching new components samples in accordance with the system of standards ISO 23953-2: 2005 (E). Described technical characteristics of the trade refrigerating equipment model M400S+. On the basis of commercial display freezer, in accordance with the technical documentation and production process supervisions carried out, an overview of the principal refrigeration system, its features and features of the cycle of operation of the refrigeration system, the description of the structure of the freezer, the principle of mounting the components and the features of the location of the refrigerating system equipment are carried out. Laboratory research was carried out on the temperature regime of the refrigeration system, a detailed description and graphical visualization were created in accordance with the obtained results, in the process of getting into the regime and during the work in the given temperature regime for the period of work. The analysis substantiated the necessity of creating a unified system for calculating commercial refrigeration equipment, for increasing efficiency and reducing design time. A detailed analysis of the market of refrigeration equipment and consumer needs was carried out. The necessity to increase the energy efficiency of products by switching to new refrigerants (natural) and introducing changes to the cooling system have been identified. The detailed description of the features of the heat-exchange devices of the system has been investigated and carried out, their structure, operation principle, and methods of installation according to the conducted observations in the process of production are described. It is necessary to pay attention to the universalization of the production of equipment, taking into account the technical requirements of the components and, accordingly, the diversity of product assortment.

The results of the laboratory and analytical research confirmed the need to increase the energy efficiency of the equipment under consideration, with the preservation or reduction of the cost price of the products.
\end{abstract}

Keywords: Refrigeration equipment; Temperature; Power consumption

\section{References}

1. Evans, J.A., Swain, M.V.L. (2010) Performance of retail and commercial refrigeration systems. IIR ICCC2010, Cambridge, UK.

2. Tassou, S.A., Ge, Y., Hadawey, A., Marriott, D. (2011) Energy consumption and conservation in food retailing, Applied Thermal Engineering, 31(2), 147-156. DOI: https://doi.org/10.1016/j.applthermaleng.2010.08.023
3. Juka: site. Electronic resource, available at: https://juka.ua/ (Accessed 3 July 2018)

4. Juka: site of the partners. Electronic resource, available at: http://juka.com.pl/ (Accessed 3 July 2018) 